\title{
AFFECTIVE AND EMOTIONAL DIMENSIONS OF BUILT SPACE: ASSESSMENT OF THE RISK REDUCTION PROCESS - HERITAGE AS A STABILITY BENCHMARK IN THE SUSTAINABLE CITY
}

\author{
CRISTINA OLGA GOCIMAN ${ }^{1}$, CRISTIAN IOSIF MOSCU ${ }^{1} \&$ MONICA GEORGIANA ENE $^{2}$ \\ "Ion Mincu" University of Architecture and Urban Planning, Romania \\ ${ }^{2}$ Bucharest University of Economic Studies, Romania
}

\begin{abstract}
The analysis of the historical evolution, the conformation of the built space has revealed the sustainable and resilient character of the historic settlements, becoming a codex of good practices for the contemporary. In this context, the protection of heritage and tradition as an appeal to identity preservation can provide the stability and balance necessary for community survival in case of risk. The historical and architectural value have exclusively constituted the criteria for identifying built objects to be preserved, but over time, the interest has expanded to the space with ambiental value as a whole, as well as to those minor components that derive meaning "from their co-existence", contributing to defining the affective value of it. Each built place has an initial aspiration, it translates a history of edification and existence, becoming for us a perpetual testimony and revelation. The place is loaded with his story, with its cultural dimension, becoming a mental reality. In our study we developed the analysis of the affective and emotional value of space, which will be changed in relation to the citizen profile, culture, education, personal and community experience. Therefore, space is not only a physical content but a living experience. The research is based on the case study of the destructured area by the demolition and investments of the communist ruler Nicolae Ceaușescu during the 1980s as a pretext for post-disaster management (after the 4 March 1977 earthquake) and which caused the loss of many monuments and a strong trauma to the deployed population. We propose a methodology of intervention in the affected area on a multicriterial assessment in terms of the balance between the value of the spatial resource reporting value and the spatial resource status.
\end{abstract}

Keywords: built space, emotional value, heritage, living experience, risk reduction, affected area.

\section{INTRODUCTION}

The extensive application of the principle of ecosystem approach from living biological systems to the built space has created the premise of an in-depth understanding of the components' relationship and equilibrium mechanism, one of the most important principles of the sustainable development.

Protecting the built ecosystem means conserving the components and specific relationships without blocking its development processes. Conscious management of turn over relationships, both in terms of needs and responses, creates the premises of a transgression of essences, capable of opening and incorporating any manifested gesture as a fiction of a future tradition and sedimentation of heritage.

The essentialization of living the space, along the way from peculiarity to generality, crosses accumulations and successive selections. Localization in the topo-climatic space, the orientation, the dominance of the material, the spatial configuration and the decorative conformation, the ethnic, religious and aesthetic mark are steps of a successive selection that gives the constructions authenticity and then, will define in time the essentialized representativeness and the rarity like cultural values.

The historical and architectural value have exclusively constituted the criteria for identifying built objects to be preserved, but over time, the interest has expanded to the space 


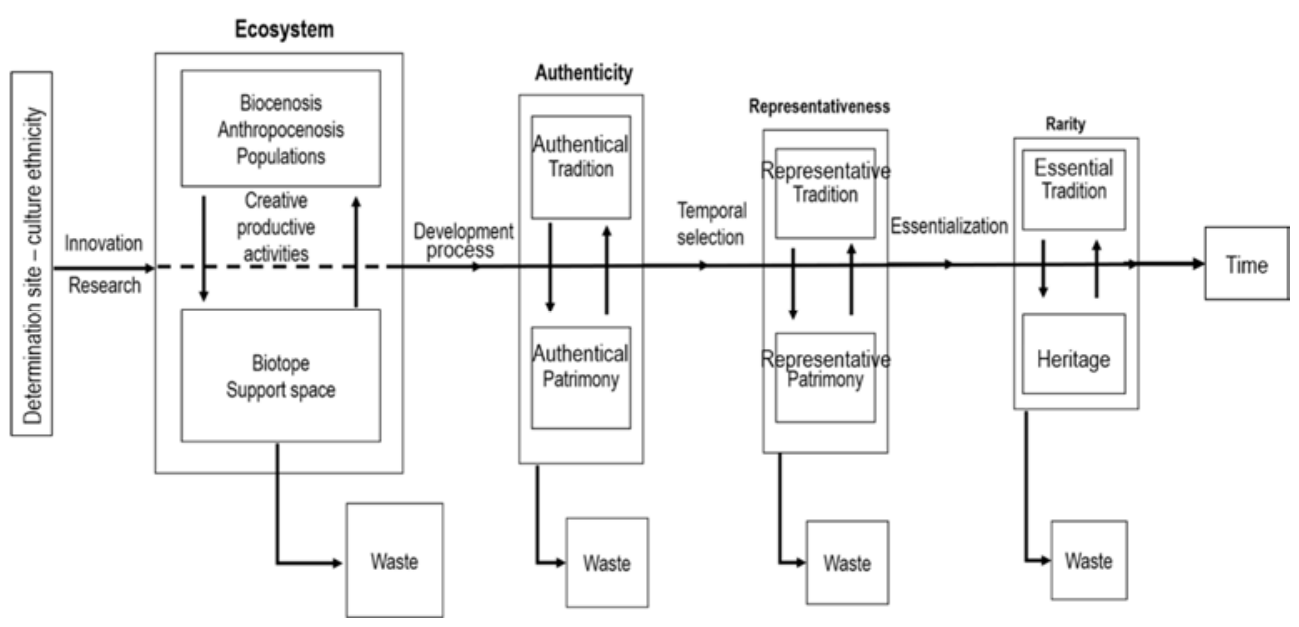

Figure 1: The evolution of built space ecosystem [1].

with ambiental value as a whole, as well as to those minor components that derive meaning "from their co-existence", contributing to defining the affective value of the built space.

"Cultural and natural heritage, with their related technologies, practices, skills, knowledge systems and ecosystem's goods and services can play an important positive role in reducing risks from disasters at all phases of the process (readiness, response and recovery), and hence in contributing to sustainable development in general" [2].

Choay in The Allegory of the Heritage highlights the relationship between the historical heritage and its acceptance by the communities as a milestone and support for continuity [3].

In his book, Existence, Space \& Architecture, Norberg-Schulz decodes the hierarchy of the levels of existential space, referring to the man and his actions: illustrating the cognitive theory of space [4].

From the architectural point of view, the levels of the existential space can be identified by three mediums recognized by the population of a settlement that develops itself in its own territory: the individual environment, the proximate and the global environment in direct interaction with the user as an individual, group or population.

The built space proposes to each receiver a particular representation of it, the perception is only realized by an analysis of spatial representations, these being closely related to the mental representation that the individual group or population has about his surroundings and the way he receives the information as a message.

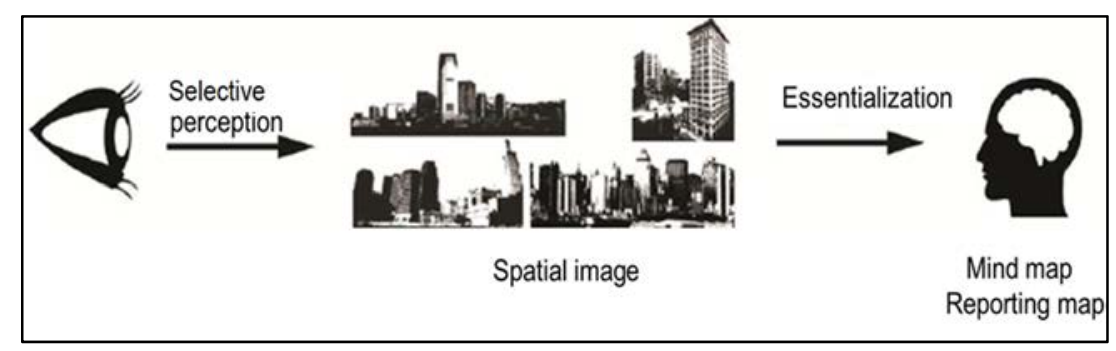

Figure 2: Spatial image perception and essentialization [1]. 
"The image map" [5], who each of us carried in our mind, is in part, sequential and sectorial, the known areas are linked by linear visual flows, corresponding to the movement axes. The clearest areas of the mental map are those related to events and activities, thus to the recognition and affective identification of the individual's relationship with the built space.

The transfer and reflection in the subjective image of the mental "map" is accomplished through the main perceptual criteria [5].

Hajer and Reijndorp in In Search of New Public Domain identifies a relation between the space built and the human perception determined by the patrimonial correspondence [6]. Wolpert declares that the spatial foot print belongs to the personality of everyone and its destructuring creates instability and stress [7]. Gehl says in his book, Life between Buildings: Using Public Space, that the development of the urban space depends by the containing activities [8].

The evaluation criteria of certain spaces consider both the affective perception and the selective one related to the connectivity qualities which can be identified by sociological investigation.

\section{THE CONCEPT OF PLACE}

The concept of place was defined by Aristotle in Physics - Book I, as the first limit, the edge of the content [9]. In a temporal determination, Hegel defines the place as "time in space" [10]. Each built place has an initial aspiration, it translates a history of edification and existence, becoming for us a perpetual testimony and revelation.

The place is loaded with his story, with its cultural dimension, becoming a mental reality and is mobilized with cultural landmarks. "Monuments as well as books are time commented", said Eliade [11]. Houses, streets, squares, city parks represent a vital, diffuse tissue in which we are born, play, learn, love, work, and sometimes die, keeping it in the fundamental substrate of consciousness as a permanent community spatial and temporal localized.

In order to understand the becoming of the individual, the value of "topo-analysis" must be specified, meaning the analysis of the place of childhood, which equally to psychoanalysis, leads to knowledge of the self. The places where the man gains his first experiences marks and shapes him by categorically influencing his personality. It is characteristic that from childhood we remember more places, moods and not chronological data. Character formation takes place in the first five years of life. According to Piaget and Inhelder [12], the sensorimotor stage of intelligence depends directly on the space.

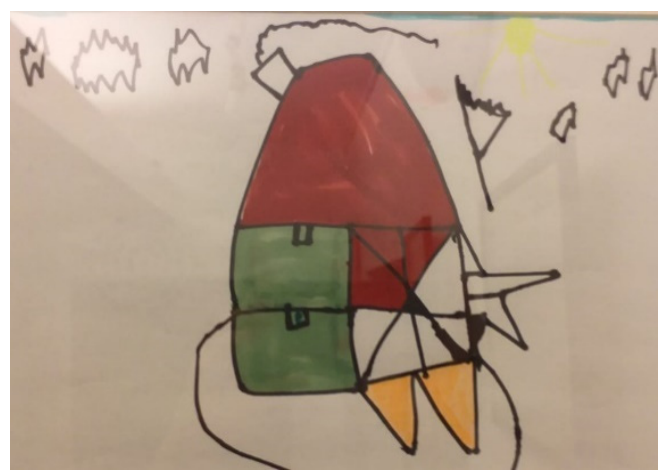

Figure 3: Human house. (Source: Drawn by the author's granddaughter (5-year-old Mina).) 
The age of childhood is one of the few common universal experiences. Quoting Schachtel, "The faith of mankind in a lost paradise is reflected in people's faith in a happy childhood. A conscious or unconscious amnesia erases all negative experiences and preserves the positive ones" [13].

Children are a non-negligible part of the population and have always been the symbols and bearers of our hopes. Therefore, it is normally to question what the society holds for them. [14].

"The only true paradise is a paradise that we have lost", wrote Proust in Time Regained

The existential dimension of the space is redeveloped on the concept of "genius loci" involving a decodification of the spatial-temporal scale of reality [15]. For Norberg-Schulz, protecting and preserving the idea of "Genius loci" means maintaining the essence of a place in an ever-changing historical context. Although the structure of a place changes over time, the spirit of the place must be maintained, Norberg-Schulz defines "stabilitas loci" as an essential condition for human existence [15]. Rossi uses the "term place" to describe the singular and universal relationship between a certain building in that place [16]. The comparative study of the different theories about the relationship between place and man will represent the theoretical support and the starting point to explore the mutations that take place in the identity and memory of the community.

The theme of place identity also appears in the work of Blaga, especially in the work Trilogy of Culture in which he speaks about the spatial horizons generated in the individual or collective unconscious that underlies the specific spatial feeling of each culture [17]. Blaga identifies a close relationship between the place where people live, the culture and the specific space they generate [17].

\section{SPATIAL LIVING/FEELING/EXPERIENCE}

Spatial living is an extremely complex but vague notion, as well. The fundamental attachment to cave or cage space is identified with the unborn child's native space. The growth and the becoming will be marked by understanding and owning other spaces, such as house, school, church, public spaces, production that will be associated with other types of emotions, soulstates or social communion. These lived experiences will develop fundamental values, love, respect, self-help, performance, courage, sacrifice, as well as the aesthetic categories of ugly and beautiful specific to human evolution.

\subsection{Artist and user space}

Differences in the perception of silent space more obvious in the case of artistic works. "How many original artists exist, so many worlds we have at our disposal", argues Proust in Elstir - About Art [18]. Each artist perceives and plays the filtered world through his own experience and sensitivity.

Dufrenne examines in the Phenomenology of Aesthetic Experience the difference between catharsis - that internal burning of the creative artist creating the aesthetic object, and that of the receiver [19].

In order to produce us in the world of people, "the aesthetic must mobilize both the aesthetic life of the creator and the aesthetic experience of the user" [19]. In the same way, the spectator who lives the spaces created by the architect or the receiver who feels artists's work, will communicate with them through his aesthetics perception based on education, but also through the perception of affection. "Thus, the solidarity of temporality and spatiality in the subject leads to an understanding of the spatialization of time in space temporalization". 


\subsection{Traveller's space}

Different from the individual's formative space, a special one is the space of the traveller "trying to find that happiness that encompasses you in the discovery of a country and which always appears in the first moments of the novelty as a land of promise" [20]. The journey thus becomes a reviewing of the past temporalities capable of evoking the happiness of knowledge.
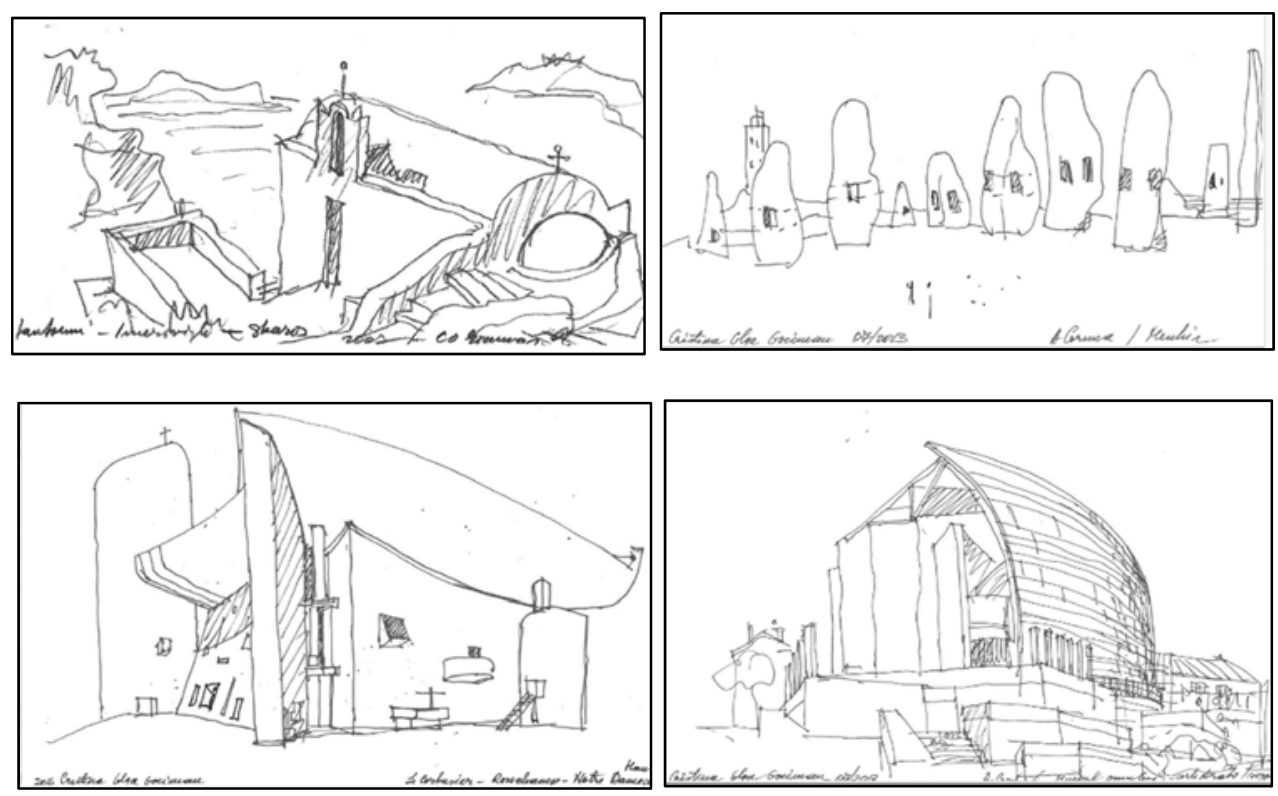

Figure 4: Cristina Olga Gociman's traveling drawings. (Source: Author.)

The perception of the traveller may differ from the perception of the living - inhabitant revealing other values that should be protected.

\subsection{Evolution of community space}

Baum explains how the emotional level of the space creator can trigger the user's emotional perception [21]. This emotional transfer can support the community project. Emotional involvement is a gateway to understanding projects, argues Ferreira [22].

Of course, these subtle analyses can be made at the level of a community in order to establish identity marks/milestones that have multiple cultural, aesthetic, functional, emotional values without which the being loses its stability.

Overlapping will generate a selection space with the vocation of a witness of a group, community, or people. Value systems imposed by erudition by elitist groups can impose cultural policies to preserve heritage and tradition. Value systems determined subtly by psycho-social investigations of an individual, group or community can generate the perception of living space, lived with roots in the experience of affection. 


\subsection{Relation in/with place}

If we are talking about a spatiality of Dasein, then it is obvious that this "fact-of-being-inspace" (being-in-the-World) must be conceived from the way of being of this being [23]. At a first reading, the reader of Sein und Zeit written by Heidegger will have some difficulties in uncovering the identity of the two notions of the book and the existing relationship between them. The most suggestive one is to say that the first notion is the anatomy of existence, while the second is the physiology of existence.

The admiration can be mediated through education, in context a static appreciation of a space, while the living of that space can assure us the existential living, which guides us to the obsessive identity recreation of the itinerary. Together with being, consciousness and finitude - sex, race, age, place, ancestry, caste, language and religion make up the circle of the limits within which gravitational (initial) freedom is exercised as conditional freedom. For all these limits constitute its conditions of practice, the firm ground from which it rises, the system of fences from which it manifests itself as freedom. "Before I build my own decisions, I am what I am through the boundaries I have received. The distance between the intimate foreign fund and the lot of my freedom is the distance between the received self and the constructed self", said Liiceanu [24].

\section{EMOTIONAL ANALYSIS/ AFFECTIVE VALUE OF SPACE}

In this study we proposed to develop a special type of analysis of the built space through emotion in relation with it, which develops an affective value of the space, being the fourth component of the reporting value. In our previous proposal, we have identified three components of the reporting value, i.e. cultural, functional, and affiliation values.

For each of the 10 possible attachments we have proposed an evolution of the intensity of the feeling from 0 to 5 . The average value will generate the 6 affective values from very high, high, medium, low very, low and negative.

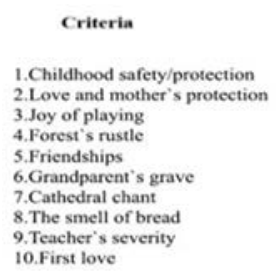

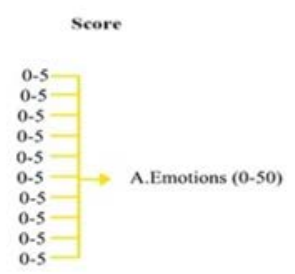

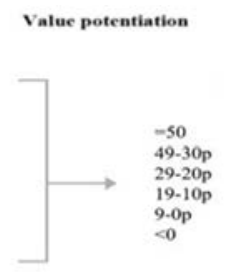

Figure 5: Affection value [1].

These values will be introduced in the initial matrix at the reporting value formed from the cultural, functional and identity value making it more sensitive.

Of course, other types of values can be identified, attachments identified based on sociological investigations.

\section{DELIBERATE THEORY/ PARTICIPATIVE MANAGEMENT}

This analysis of the exposed elements will identify reporting value of the support space level and determine its physical state value. The relationship between the two values will suggest the intervention methodologies in territory in order to preserve the identity, as well as the safety status of the community. 


Criteria
1. Age / Historic analysis
2. Architectural concept/
Morpho-typology/ Language
3. Artistic concept/ style
4. Functional concept
5. Technical / technological concept
6. Execution concept
7. Materiality
8. Location / Site
9. Furnishing decoration
10. Author concept

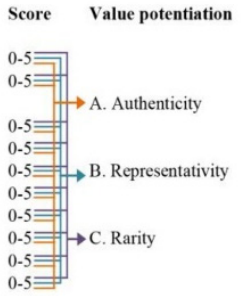

Value type

1. I Buildings with high risk level Essential equipment

2. II High degree of temporary occupancy Special protection degree for persons 3. III Current buildings and constructions 4. IV Low importance buildings

5. A Constructions of exceptional importance 0

6. B Constructions of special importance

7. C Constructions of normal importance 8. D Constructions of low importance

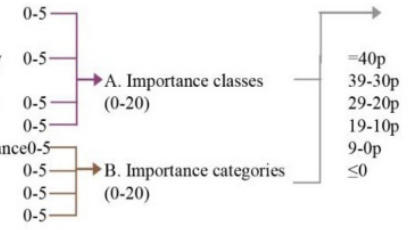

1.Tradition value

2.Memorialistic value

3.Mytology value

4. Religious value

5. Ethnic value

6. Political-ideological value

7.Local/regional/national value

8.Spiritual value

9.Symbolic value

10.Collective attachment value

1.Childhood safety/protection

2.Love and mother's protection

3.Joy of playing

4.Forest's rustle

5.Friendships

6.Grandparent's grave

7.Cathedral chant

8.The smell of bread

9. Teacher's severity

10.First love
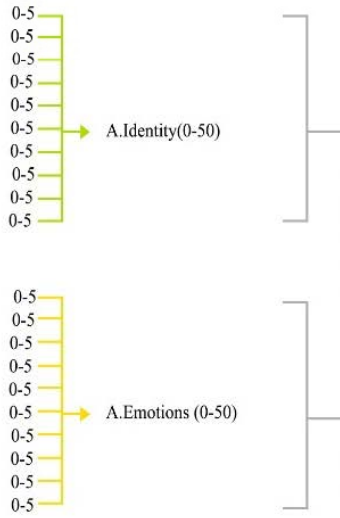

igh affiliation value 49-30p Typological affiliation value 29-20p Ambient affiliation value 19-10p Minor affiliation value

9-0p Affiliation value missing
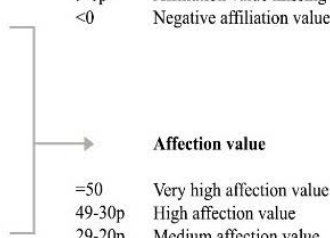

egative affiliation value

\section{Affection value}

Very high affection value High affection value Medium affection value

Low affection value

9-10p Low

-0p Very low affection value

Negative affection value

Status value

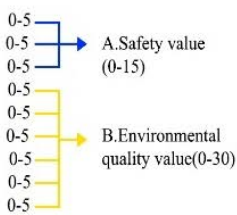

\section{$=45 \mathrm{p}$}

44-30p Collapse A+B

19-10p Poor A+B

$9-0 \mathrm{p} \quad$ Medium $\mathrm{A}+\mathrm{B}$

$<0 \quad$ Good $A+B$

Very good $A+B$ 29-20p Very poor $A+B$
Reporting

value (0-5) Very high 5

High 4

Medium 3

Low 2

Very low 1

Negative 0

1.Structural vulnerability

2.Safety of exploitation

3.Fire safety

4. Energy consumption

5.Hygiene-sanitary configuration

6.Thermal protectio

7.Sound protection

8.Hygro-technical protection

9.Control of natural light

Intervention

decision

Figure 6: Value analysis of the built space. Support methodology of the intervention strategies [1]. 


\begin{tabular}{|lll|}
\hline & Code & Interventions categories \\
Maintenance & A & Current maintenance: strenghtening \\
& B & Conservative maintenance: local consolidation interventions \\
Amelioration & C & Conservative works: for conservation and insurance of functionality of the building \\
Transformation & D & Restoration and consolidation strenghtening \\
& E & Partial restricting: demolition and reconstruction works for certain components, including structural ones. \\
& F & Global restricting: demolition and reconstruction works for some components, including structural ones, \\
which imply the complete transformation of the building \\
Replacement & G & Demolition \\
& H & New proposals
\end{tabular}

Figure 7: Intervention and decision categories in protected areas [1].

\section{MONUMENT AND NEIGHBOURHOOD RELATION WITH INHABITANTS: CASE STUDY}

As a result of the different stages of development in its history, Bucharest is a city to which the description of an urban palimpsest can be easily assigned, being composed of different areas that have a particular character but also a number of specific problems, which are fully represented in our study area.

The relationship of continuous content can change over time in a natural, organic, or brutal way, as in the situation of many monuments on the Arsenal Hill in Bucharest, the place where Nicolae Ceausescu focused his demolitions to free the altered land and to locate the People's House. The monstrous building of the People's House is the second building after the Pentagon, $110 \mathrm{~m}$ high, $275 \mathrm{~m}$ high and 6.3 hectares occupied area. The historian Giurescu pointed out in a documentary filmed for the TVR cultural television, the hallucinatory proportion of the demolitions in this perimeter: "Bucharest had the characteristics of a Byzantine city, they destroyed a sixth of the city, the equivalent of Venice as square meters.

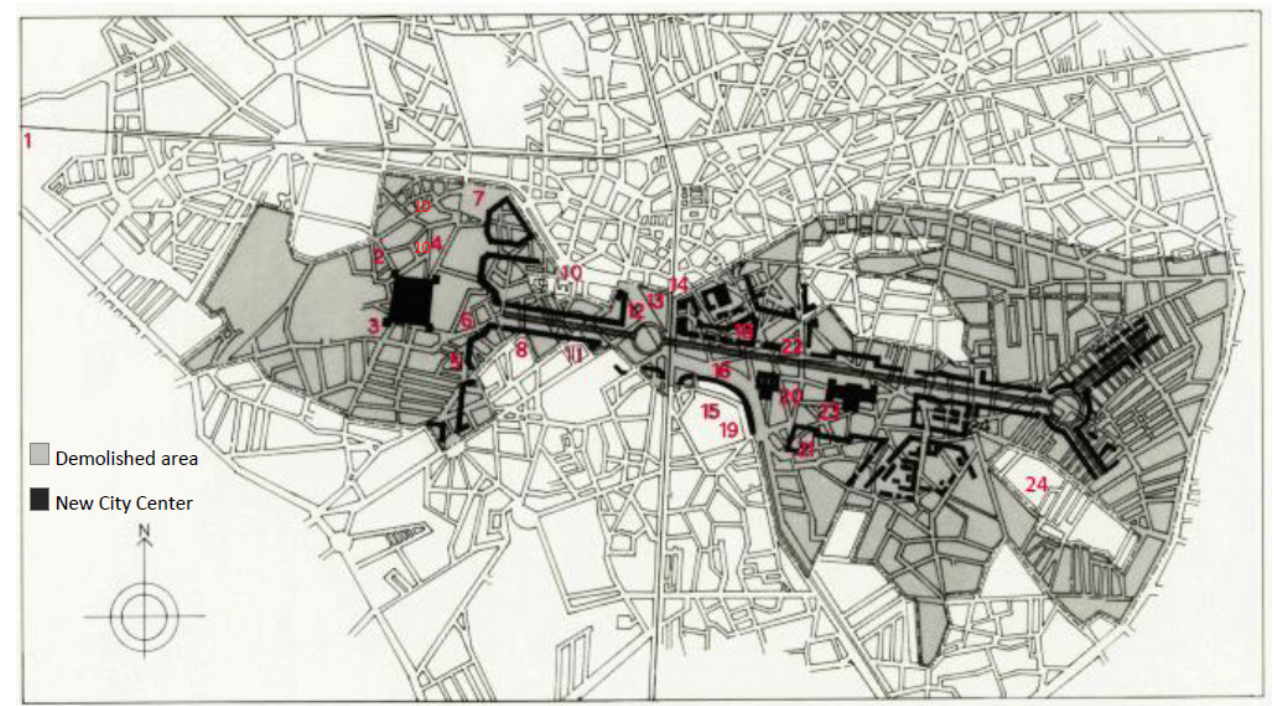

Figure 8: City of Bucharest, Romania, destroyed or re-located monuments. Source: M. Cavalcanti. Totalitarian states and their influence on city-form: The case of Bucharest, 1992 [1]. 
A representative area, the old Bucharest's heart was amputated, in order to obtain the possibility of making a new city, which does not relate to other values of the past, but only to themselves" [25].

The case of Bucharest was studied in comparison with Paris, Moscow, Berlin and Rome, during the periods of authoritarian or totalitarian regimes, where the heritage was totally or partially affected [26].

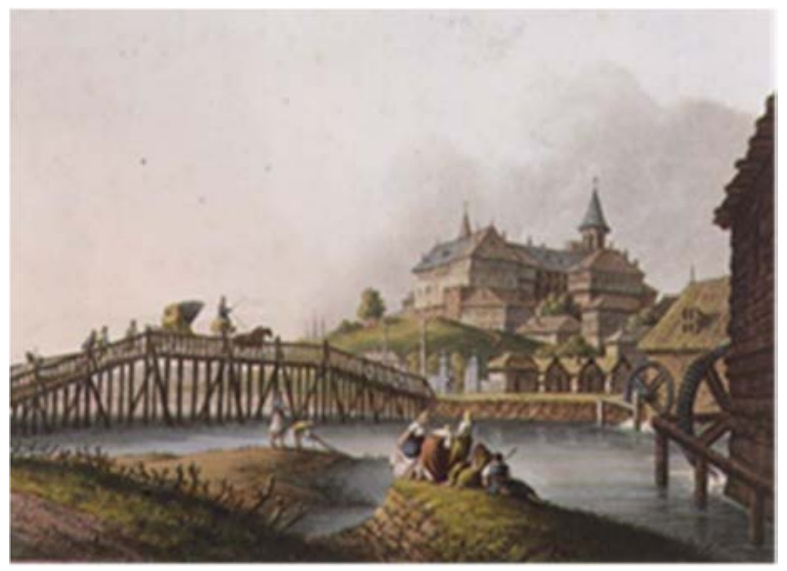

Figure 9: Mihai Vodă church painted in 17th century [1].

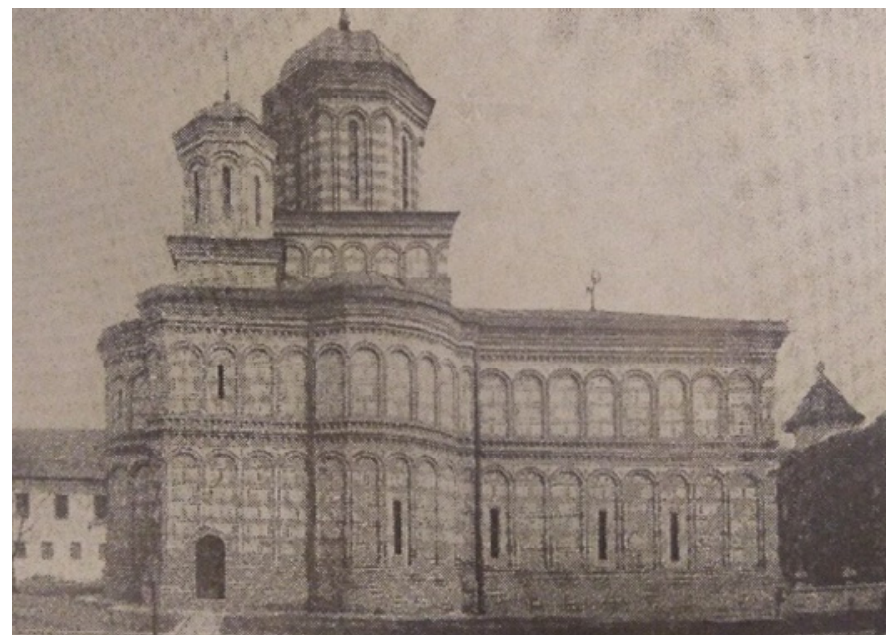

Figure 10: Mihai Vodă church inside the assembly [27].

Arsenal Hill is one of the oldest archaeological sites in Bucharest, with paleolithic relics being discovered here. The continuous dwelling of this space is evidenced by Dacian traces, churches and princely courts, such as the Monastery of St. Nicolae, 1589, founded by the ruler of that time, Mihai Viteazul. 
A special image of the 17th century Mihai Vodă monumental complex is that of the painter Luigi Mayer, who accompanied the Ambassador of Great Britain, Robert Ainslie, on his trips to Constantinople. On the basis of Mayer's drawing, the artist William Watts made a valuable color engraving of the "Mihai Vodă" monastery.

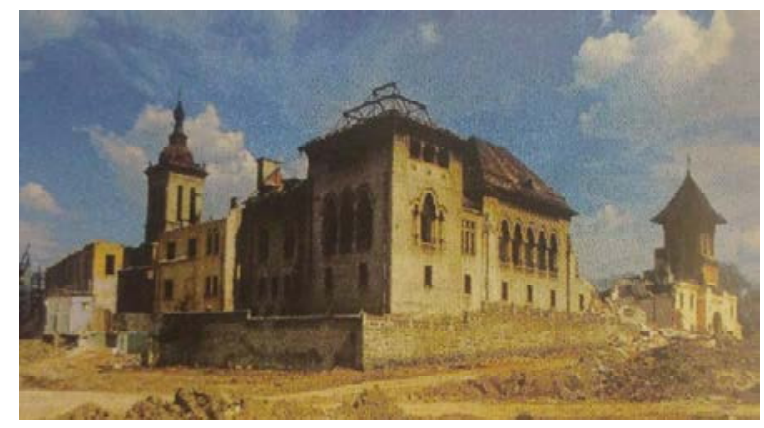

Figure 11: Mihai Vodă church demolish site [28].

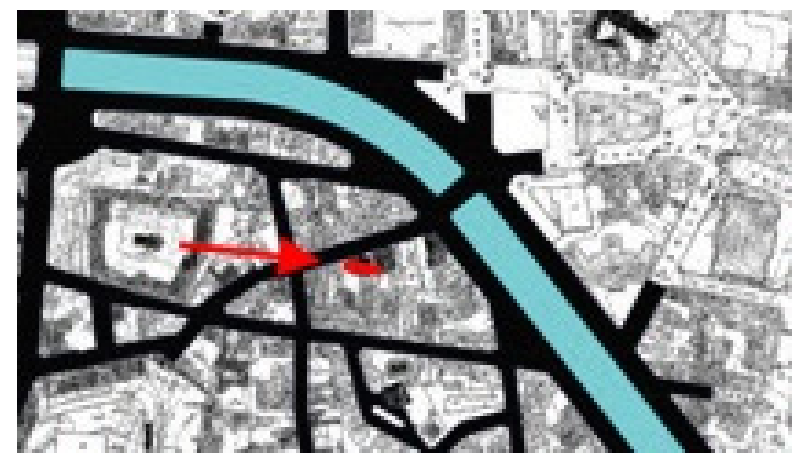

Figure 12: Relocation plan of Mihai Vodă church. Initial location versus new location. Bucharest Urban Plan 1974 [1].

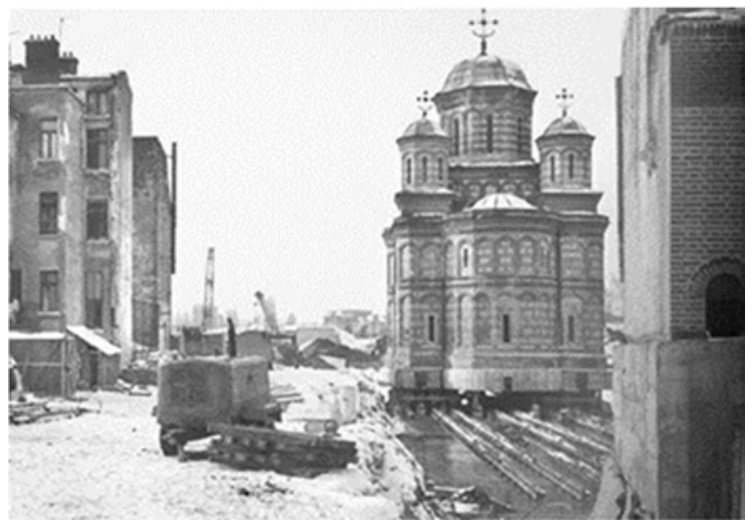

Figure 13: Mihai Vodă church translation in January 1986, Bucharest, Romania [29]. 


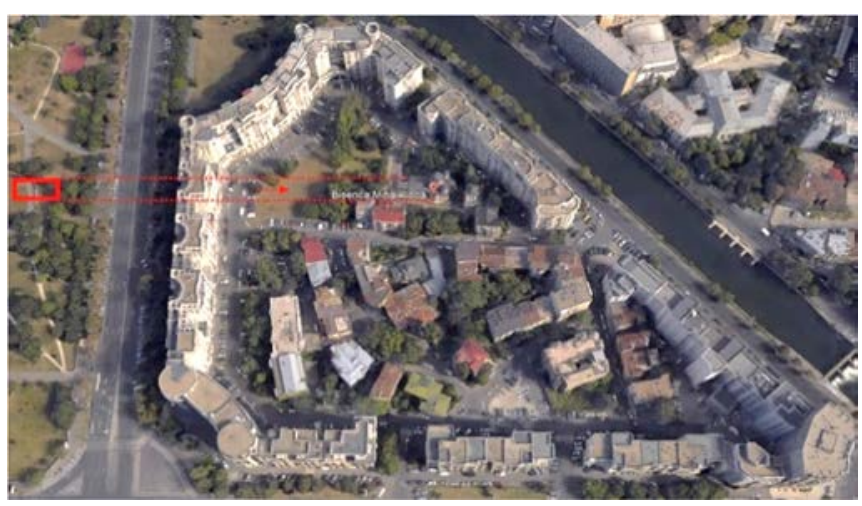

Figure 14: The study area and the relocating distance [1].

The church of Mihai Vodă generated around an austere monastery premises, then completed other state institutions such as the Arsenal of the Army and the State Archives becoming a cultural and functional ensemble, high in value and spatial coherence. Destroying the neighbourhoods and translating it relocated by $241.9 \mathrm{~m}$ of which $197 \mathrm{~m}$ on a $2.8 \%$ slope, according to the engineer Iordăchescu [30] it saved the object but destroyed the context. Her relocation in back front of high blocks distorted her spatial perception.

\begin{tabular}{|c|c|c|c|c|c|c|c|c|c|c|c|}
\hline \multicolumn{10}{|c|}{ Reporting value } & \multirow{2}{*}{\multicolumn{2}{|c|}{ Status value }} \\
\hline \multicolumn{4}{|c|}{ Cultural value } & \multicolumn{2}{|l|}{ Functional value } & \multicolumn{2}{|l|}{ A ffiliation value } & \multicolumn{2}{|l|}{ A ffection value } & & \\
\hline Criteria & A. Autenticits & \begin{tabular}{|c|} 
B. \\
Represen- \\
tativity
\end{tabular} & C. Rarity & Criteria & $\mathrm{p}$ & Criteria & $\mathrm{p}$ & Criteria & $\mathrm{p}$ & Safety & $\mathrm{p}$ \\
\hline Age/ historic analysis & 5 & 5 & 5 & $\begin{array}{c}\text { I B uilding with high } \\
\text { risk level Essential } \\
\text { equipment }\end{array}$ & & Traditional value & 5 & $\begin{array}{l}\text { Childhood safety/ } \\
\text { protection }\end{array}$ & 3 & $\begin{array}{l}\text { Structural } \\
\text { vulnerability }\end{array}$ & 3 \\
\hline $\begin{array}{c}\text { Architectural concept/ } \\
\text { morpho-typology/ } \\
\text { language }\end{array}$ & 5 & 5 & 5 & $\begin{array}{c}\text { II High degree of } \\
\text { temporary } \\
\text { occupancy Special } \\
\text { protection degree } \\
\text { for persons }\end{array}$ & 4 & Memorialistic value & 2 & $\begin{array}{c}\text { Love and mother's } \\
\text { protection }\end{array}$ & 3 & $\begin{array}{l}\text { Safety of } \\
\text { exploitation }\end{array}$ & 2 \\
\hline Artistic concept & 5 & 5 & 5 & $\begin{array}{l}\text { III Current } \\
\text { buildings and } \\
\text { constructions }\end{array}$ & & Mythology value & 2 & Joy of playing & 3 & Fire safety & 3 \\
\hline & & & & IV Low importance & & & & & & Total & 8 \\
\hline Functional concept & 5 & 5 & 5 & buildings & & Religious value & 5 & Forest's rustle & 0 & Environment quality & \\
\hline $\begin{array}{c}\text { Technical/ technological } \\
\text { concept }\end{array}$ & 5 & 5 & 5 & $\begin{array}{c}\text { A Constructions of } \\
\text { exceptional } \\
\text { importance }\end{array}$ & & Ethnic value & 5 & Friendships & 3 & $\begin{array}{l}\text { Energy } \\
\text { consumption }\end{array}$ & 1 \\
\hline Execution concept & 5 & 5 & 5 & $\begin{array}{l}\text { B Constructions of } \\
\text { special importance }\end{array}$ & 4 & $\begin{array}{c}\text { Political - ide ological } \\
\text { value }\end{array}$ & 5 & Grandparent's grave & 0 & $\begin{array}{c}\text { Hygiene-sanitary } \\
\text { configuration }\end{array}$ & 0 \\
\hline Materiality & 5 & 5 & 5 & $\begin{array}{l}\text { C Constructions of } \\
\text { nomal importance }\end{array}$ & & $\begin{array}{l}\text { Local/ regional/ } \\
\text { national value }\end{array}$ & 5 & Chatedral chant & 5 & Thermal protection & 1 \\
\hline Location/ Site & 5 & 5 & 5 & $\begin{array}{c}\text { D Constructions of } \\
\text { low importance }\end{array}$ & & Spiritual value & 5 & The smell of bread & 0 & Sound protection & 0 \\
\hline Furnishing decoration & 5 & 5 & 5 & & & Symbolic value & 5 & Teacher's severity & 0 & $\begin{array}{c}\text { Hydro-techrical } \\
\text { protection }\end{array}$ & 0 \\
\hline \multirow[t]{2}{*}{ A uthor concept } & 5 & 5 & 5 & & & $\begin{array}{c}\text { Collective attachment } \\
\text { value }\end{array}$ & 5 & First love & 0 & $\begin{array}{c}\text { Control of naturalm } \\
\text { light }\end{array}$ & 1 \\
\hline & & & & & & & & & & Total & 3 \\
\hline \multirow[t]{2}{*}{ TOTAL } & 50 & 50 & 50 & & 8 & & 44 & & 17 & & 11 \\
\hline & \multicolumn{2}{|c|}{$B+C>50$} & 5 & & 4 & & 4 & & 2 & & \\
\hline Reporting value & \multicolumn{9}{|c|}{$15 / 4-3,75 \sim 4$} & Status value & 2 \\
\hline
\end{tabular}

Figure 15: Table of build space evaluation Mihai Voda church area. 


\begin{tabular}{|c|c|c|c|c|c|c|}
\hline \multirow[b]{2}{*}{ Reporting Value } & \multicolumn{6}{|c|}{ Status Value } \\
\hline & 0 & 1 & 2 & 3 & 4 & 5 \\
\hline 5 & A & B & $\mathrm{C}$ & $\mathrm{D}$ & $\mathrm{F}$ & $\mathrm{F}$ \\
\hline 4 & $\mathrm{~A}$ & B & C & $\mathrm{D}$ & $\mathrm{F}$ & $\mathrm{F}$ \\
\hline 3 & A & B & C & $\mathrm{E}$ & $\mathrm{F}$ & $\mathrm{G} / \mathrm{H}$ \\
\hline 2 & A & B & D & $\mathrm{E}$ & $\mathrm{F}$ & $\mathrm{G} / \mathrm{H}$ \\
\hline 1 & A & $\mathrm{C}$ & $\mathrm{D}$ & $\mathrm{E}$ & $\mathrm{F}$ & $\mathrm{G} / \mathrm{H}$ \\
\hline 0 & B & $\mathrm{C}$ & $\mathrm{D}$ & E & $\mathrm{F}$ & $\mathrm{G} / \mathrm{H}$ \\
\hline
\end{tabular}

Figure 16: Reporting value and status value system matrix for Mihai Vodă church [1].

Following the application of the value analysis, the Mihai Vodă church has the maximum reporting value 4 and the status value 2 , which according to the matrix will lead us to type $\mathrm{C}$ conservation operations.

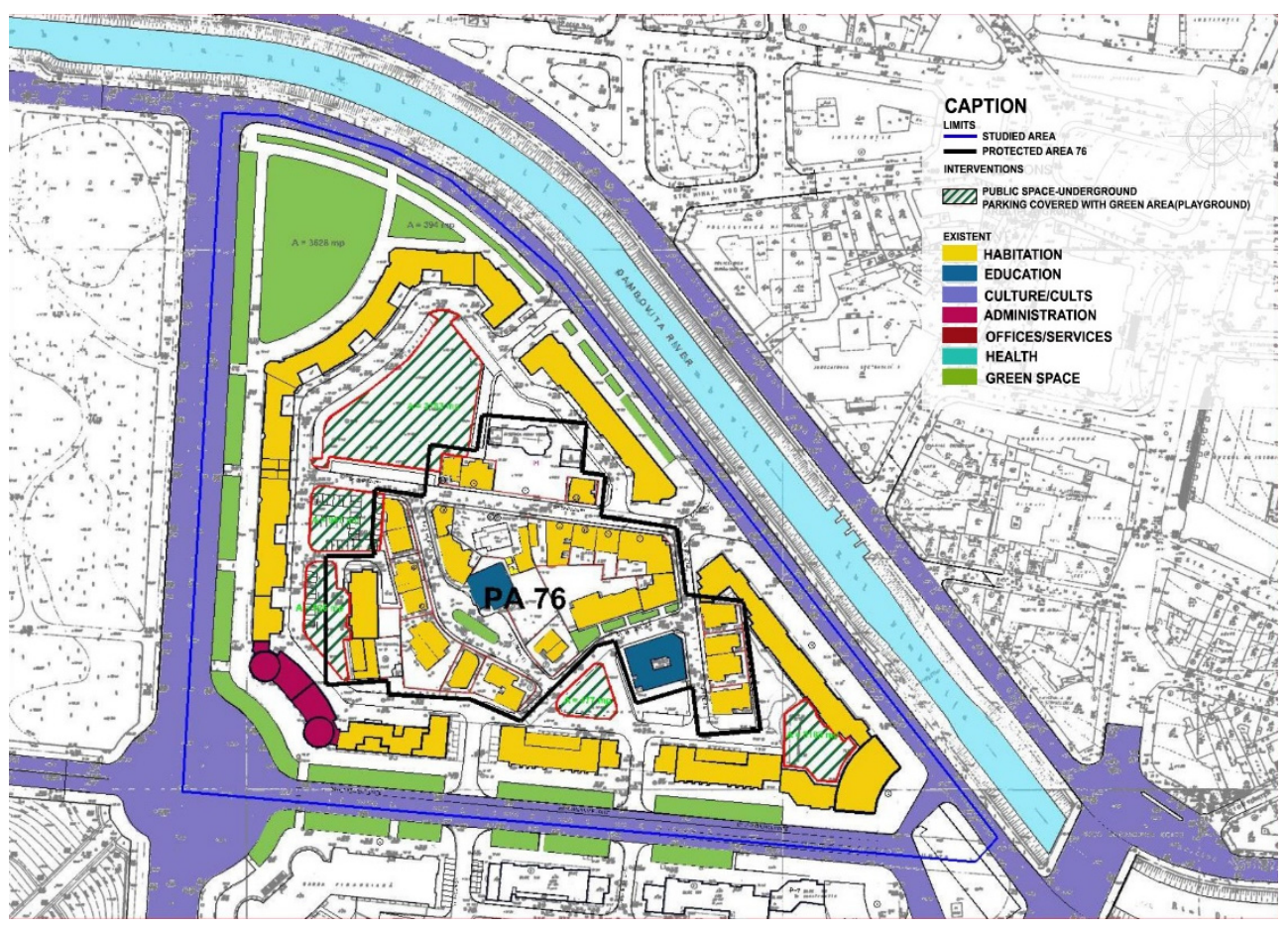

Figure 17: Example of intervention of parking - shelter space covered by green roof and playground for children [1].

In this context, where the opinions of the majority can be prevalent, of course, in the conditions of respect for human rights, the evaluation system proposed through a project based on sociological surveys introduces the rigorously selected criteria, explicitly and hierarchically valued in support of the decisions of the communities. The proposed solution was to create a green screen of protection between the monument and the neighbourhood, to 
provide a playground for children on the semi-buried car parks can be a possible shelter and the relocation space for possible affected people from neighbourhood. In the deliberative process, citizens exchange ideas, propose solutions, affirm needs, being trained on the theory of public reason [31].

At this point of the analysis comes the question - who proposes and who approves the intervention of the urban space in the sense of its cultural, functional, emotional restitution and ensuring structural stability and security? Habermas proposes through the deliberative theory of all those involved, community, decision makers, designers, in an evaluation and selection process [32]. Deliberative theory thus becomes a component of participatory management and implicitly a premise for the resilience of space.

\section{REFERENCES}

[1] Gociman, C.O., Georgescu, S.E. \& Florescu, T., Strategii şi rezilienţă în reducerea riscului la multihazard, Editura Universitară Ion Mincu: Bucharest, 2016.

[2] World Heritage Committee, Strategy for Reducing Risks from Disasters at World Heritage Properties, Christchurch, 2007.

[3] Choay, F., Alegoria Patrimoniului, Editura Simetria: Bucharest, 1998. (In Romanian.)

[4] Norberg-Schulz, C., Existence, Space and Architecture, Studio Vista Books: London, 1971.

[5] Lynch, K., The Image of the City, MIT Press: Cambridge, MA and Harvard University Press, 1960.

[6] Hajer, M.A. \& Reijndorp, A., In Search of the New Public Domain: Analysis and Strategy, NAI Publishers: Rotterdam, 2001.

[7] Wolpert, J., Migration as an adjustment to environment stress. Journal of Social Issues, 22(4), 1966.

[8] Gehl, J., Live between Buildings: Using Public Space, Islands Press, 2011.

[9] Aristotle, Fizica Cartea VI, Traducere si note H.I. Barbu, Stiintifica: Bucharest, 1966. (In Romanian.)

[10] Hegel, G.W.F., Volesungen uber die Philosophie der Geschichte (Prelegeri de filozofia a istoriei 1822-1831). (In Romanian.)

[11] Eliade, M., Tratat de istoria religiilor, Editura Humanitas: Bucharest, 2013. (In Romanian.)

[12] Piaget, J. \& Inhelder, B., The Child's Conception of Space, Routledge \& Kegan Paul: London, 1956.

[13] Schachtel, E.G., Metamorphosis: On the Development of Affect, Perception, Attention, and Memory, Basic Books: New York, 1959.

[14] Proust, M., In cautarea timpului pierdut, Editura BPT, 1913, 1927. (In Romanian.)

[15] Norberg-Schulz, C., Genius Loci: Towards a Phenomenology of Architecture, Rizzoli: New York, 1991.

[16] Rossi, A., The Architecture of the City, MIT Press: Cambridge, MA and London, 1982.

[17] Blaga, L., Trilogia culturii, Editura pentru Literatură Universală: Bucharest, 1969. (In Romanian.)

[18] Proust, M., Elstir - Despre arta, Texte alese si traduse de Paul Dinopol, Editura Meridiane: Bucharest, 1970. (In Romanian.)

[19] Dufrenne, M., Fenomenologia experienței estetice, Editura Meridiane: Bucharest, 1976. (In Romanian.)

[20] Cantacuzino, G.M., Pătrar de veghe, Editura Dacia: Cluj-Napoca, 1977. (In Romanian.) 
[21] Baum, H., Planning with half a mind: Why planners resist emotion. Planning Theory \& Practice, 16(4), pp. 498-516, 2015.

[22] Ferreira, A., Emotions in planning practice: A critical review and suggestion for future developments based on mindfulness. Town Planning Review, 84(6), pp. 703-719, 2013.

[23] Heidegger, M., Ființă și timp, Editura Humanitas: Bucharest, 2012. (In Romanian.)

[24] Liiceanu, G., Despre limită. Editura Humanitas: Bucharest, 2019. (In Romanian.)

[25] Giurescu, D., The razing of Romania's past. A project of the Kress Foundation European Preservation Program of the World Monuments Fund, New York, 1989.

[26] Cavalcanti, M., Urban reconstruction and autocratic regimes: Ceausescu's Bucharest in its context, Planning Perspectives, 12, 1997.

[27] Curinschi Vorona, G., Istoria arhitecturii în România, Editura Tehnică: Bucharest, 1981. (In Romanian.)

[28] Celac, M., Carabela, O. \& Marcu-Lepadat, M., Bucharest Architecture, OAR B Guide, 2016.

[29] Pandele, A., Bucurestiul mutilat, Editura Humanitas: Bucharest, 2018.

[30] Speteanu, V.G., Dr. Ing. Eugen Iordăchescu. Un salvator al monumentelor de arhitectură, Editura Speteanu: Bucharest, 2010. (In Romanian.)

[31] Rawls, J., A Theory of Justice, Oxford University Press: New York, 1986.

[32] Habermas, J., Between Facts and Norms: Contributions to a Discourse Theory of Law and Democracy, MIT Press: New York, 1996. 